\title{
Architecture in transition: the case study of the dormition catedral in Volodymyr Volynskyi
}

\author{
Petro Rychkov \\ e-mail:p.a.rychkov@pollub.pl \\ Lublin University of Technology, Faculty of Civil Engineering and Architecture, \\ Department of Conservation of Built Heritage
}

\begin{abstract}
There are considered the key architectural transformations of the famous architectural monument, the Dormition Cathedral in Volodymyr (now Volodymyr Volynskyi, northwestern region of contemporary territory of Ukraine) during the XII - XIX centuries. The circumstances and motivations that have resulted in radical constructive and stylistic changes of this temple at certain stages of its existence have been retraced. The dependence of architectural changes of the temple on social, political, religious and subjective factors is revealed.
\end{abstract}

Key words: Volodymyr Volynskyi, Dormition cathedral, Greek-Catholicarchitecture, Orthodoxarchitecture, architectural transmorphism, Pavel Giżycki, Adrian Prakhov, GrigoriiKotov.

\section{Introduction}

Dormition of the Mother of God Cathedral in Volodymyr Volynsky belongs to the relatively small group of architectural monuments in Ukraine, dated back to the Old East Slavic (Old Rus') times. During its long life, the shrine was subjected to multiple changes in its original appearance. There can be separated several important stages in its history: the construction of a temple in the 1150s, a large-scale reconstruction in the middle of the $18^{\text {th }}$ century, and a massive restoration of a possible original appearance at the end of the $19^{\text {th }}$ century. The result of the last oneis visible now. Although the last restoration was based on the subjective vision of the architect and restorer, in general, it is an attempt to reproduce the general nature of the original.

\section{The first five centuries}

The first chronicle mention of this ancient Old Rus' temple dates to 1160. It is extremely concise and does not contain any details on architectural perculiarities. It is noted that Prince Mstislav Izyaslavovich built in the city of Volodymyr-Volynskyi holy church in the city and decorated it perfectly ${ }^{1}$. He subsequently was buried here in $1170^{2}$. In the future, this shrine is often referred to as the Mstislav Temple in honor of the builder.

During the $12^{\text {th }}-13^{\text {th }}$ centuries the temple remained the center of the Orthodox Volodymyr diocese, performing the functions of the cathedral. It is known that during the Tatar invasion in 1491 the Cathedral of the 
Dormition was greatly injured in the large city fire. However, Bishop Vassian managed to restore the temple in 1494 already, as mentioned in the chronicles ${ }^{3}$.

The only thing can be judged about the original appearance of the newly built cathedral is planning system. It was a rather large temple with six columns and threeapses with a length of $34.7 \mathrm{~m}$, a width of $20.6 \mathrm{~m}^{4}$ (Fig. 1). Unfortunately, the original tops of the ancient temple have been lost long time ago and today only hypothetical attempts of its graphic reconstruction are available.

The church was significantly damaged in 1565 during the battle for the episcopal post between the Orthodox bishop of Chełm Teodozy Lazowski and the nobleman Iwan Borzobohaty-Krasieński. It came to the gunfire of the cathedral with devastating consequences. Only in 1588, "negligent" bishop F. Lazovsky had to repair the temple at the insistence of the Kyiv governor, Prince Vasyl Kostiantyn Ostrozky ${ }^{5}$.

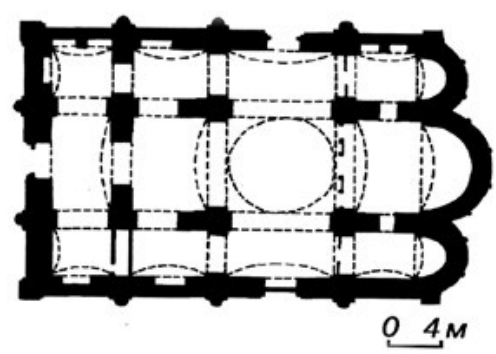

Fig. 1. Volodymyr-Volynskyi. Cathedral of Dormition of the Mother of God. C. 1260. Ground plan. After P. Rappoport (1982, p. 105-106).

\section{Convertion into the greec-catolic church}

A new stage in the history of the cathedral relates to its transition under Greek Catholic Church after the Union of Brest in 1596. Due to the active work of the first Greek Catholic bishop, the "apostle of union" Hipacy Pociej, the temple became the center of a new confession in Volhynia and achieved the highest glory.

Bishop Joahim Morochowski,successor of $\mathrm{H}$. Pociej, strengthened the episcopal mansion with a new stone fence with towers and weaponry. In the 1640s, Bishop Jozef Bakowiecki-Mokosiej built a masonry bishop's house instead of the old wooden one, near the southern wall of cathedral.

In 1683, the cathedral suffered from a citywide fire, which resulted in damage of pediments and masonry towers, and after some time and the vaults collapsed ${ }^{6}$. Former Volodymyr Bishop Lew Szlubic Zalenskyj began restoration works, which lasted several years. In this context, there is a Piotr Krasny's assumption that L. Zalensky did not confine to a simple repair of the burnt temple but made its complete rebuilding ${ }^{7}$. However, in our opinion, it is unlikely that it was subjected to radical changes. Such a restructuring would require a holistic design concept and was impossible without involving experienced architect.

Substantial changes in the appearance of the Dormition Cathedral took place already in the $18 \mathrm{c}$. under the rule of the Greek Catholic bishop and metropolitan of Volodymyr Leon Kiszka (1711-1728), who had to eliminate the consequences of another great fire. Not for nothing contemporaries characterized him as a "gloriosus restaurator". However, as Orest Lewicki stated, he did not complete the reconstruction, as in his death will there was signed twenty thousand złoty over its continuation ${ }^{8}$.

Another "reparation" of the Cathedral began in 1753 and became a milestone in its history. Bishop Teofil Godebski, who initiated that, testified that he was able to "build the Volodymyr Cathedral as different from

3 Левицкий О. И. Историческо еописаниеВладимиро-Волынского Успенского храма, построенного в половине ХІІ века князем Мстиславом Изяславичем. Киев, 1892. С. 49.

4 Раппопорт П.А. Русская архитектура Х-ХІІІ вв. Каталог памятников. Ленинград, 1982. С. 106.

5 Левицкий О.И. Историческоеописание... С. 53.

6 Op.cit. C. 68

7 Krasny P. Katedra unicka w Chelmie. O problemach badan nad architektura sakralna Kościoła grekokokatolickiego w XVIII w. // Sztuka kresów wschodnich, 1998. T. 3. S. 211.

8 Левицкий О.И. Историческоеописание... С. 71. 
other churches" ${ }^{\prime 9}$. It is evident from this statement that in fact a new shrine with late-baroque features was built. The professional level of rebuilding reveals the involving gifted architect, who managed to carry out a full-scale "conversion" of the Byzantine archetype into baroque stylistics. The stylistic handwriting of this transformation gave Jerzy Kowalczyk the idea to attribute it to famous architect of the middle of the $18^{\text {th }}$ century, the Jesuit Pawel Giżycki ${ }^{10}$. A. Betlej, the author of the monograph on P. Giyzicki's artwork, confirm this version, noting the involvement of this architect in the construction of the entrance gate ${ }^{11}$. It should also be mentioned the distinct similarity of the triangular pedaments in the old drawings of the Cathedral and the existing St. Joahim's and St. Anna's Parish Church, also designed by P. Giżycki ${ }^{12}$.

Consequently, T. Godebski's rebuilding campaign had put the final point in the long-term process of convergence of the Greek-Catholic architectural paradigm with the Baroque European experience. It was a largescale reconstructive project, the main essence of which was the "reformatting" of the old architectural structure, including the creation of a unique exonarthex. With appearance of this structure, the process of transition from the Old Ruś original with its expressive centrism to the composition of the basilica's type with a characteristic accent of the longitudinal axis and with the dominance of the western forehead facade was completed. We can only offer our own graphic version of this reconstruction (Fig. 2).

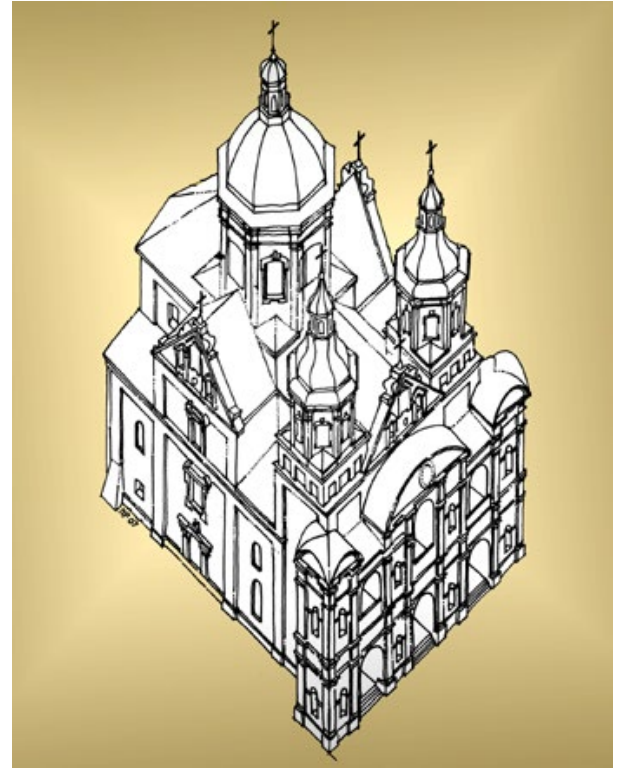

Fig. 2. The Dormition cathedral in the mid of $18^{\text {th }} \mathrm{c}$. Hypothetical reconstruction by P. Rychkov.

As a result of architectural innovations by T. Godebski,temple became about three meters longer, and its western part - by six meters wider. He also had a plan to constructa monumental brick bell tower instead of the old wooden one. He casted a huge copper bell for it 500 pounds in weight, but because of his death in 1756 these plans have not been implemented.

The characteristic planning of the Old Ruś temple and its cross-in-square structural system had much in common with the models of temple construction of those times. However, the final spatial transformations in 1753 were extremely significant, therefore it was very difficult to imagine how the temple looked like 600 years ago.

The existing iconography of the Cathedral, which reproduces the results of late baroque reconstruction, clearly illustrates this circumstance. There can be identified main components, on which this transformation was based: the fundamental changes in the spatial composition with transept separation, the extention to the 
western facade of two-level arched loggias (exonarthex), the active application of baroque forms - both in the exterior and in the interior. Based on these changes, P. Krasny did not accidentally attribute this building to the group of basilicas with double-towered façades. However, it should be noted that this characteristic refers to the rebuilt temple and is not attributed to the original ancient building.

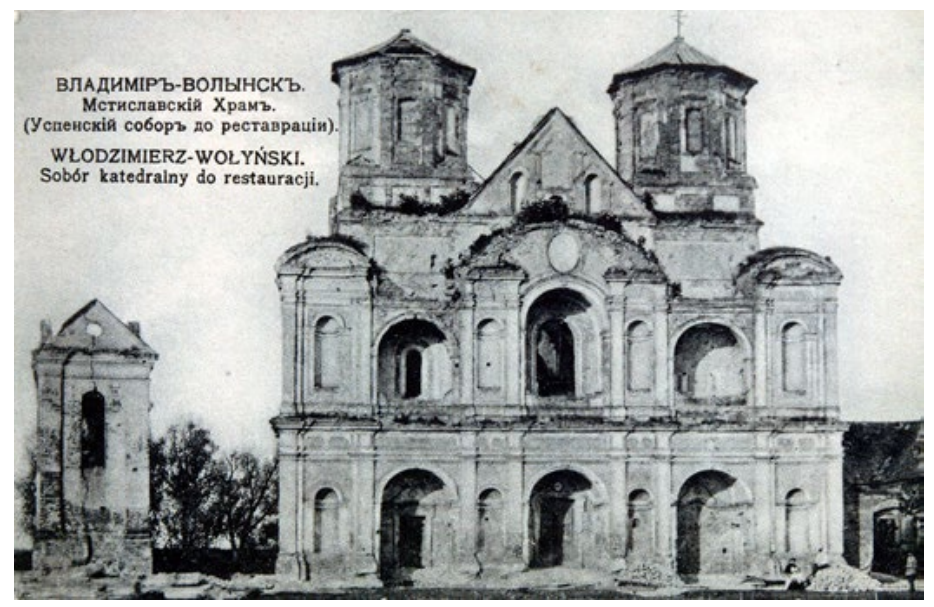

Fig. 3. West elevation of the Cathedral of Dormition. Postcard. End of $19^{\text {th }}$ cent.

The most important innovation was the extension to the western facade of exonarthex in the form of two levels of the loggia: first one at the ground level, and the second oneat the level of the choirs (Fig. 3). Both levels had three open loggias with half-circle vaults. At the same time, the central loggia of the second level was higher than the others, accentuating the main compositional axis. Screw stairs to the second level were arranged in one of the pylons. The loggias were separated by massive pylons, attached to the old western wall. Winding staircase tp second level was arranged in one of the pylons. The facade and exterior side surfaces of the pylons were decorated with paired pilasters, between which half-circle niches (loggettas) were arranged at both levels for the sculptural figures of the saints.

The creation of the exonarthex, obviously, was intended not only to make the architectural image of the Greek Catholic shrine closer to the formative traditions of European architecture. The monumental facade composition with six loggias, open to the pre-cathedralsquare, gave additional opportunities for conducting special liturgies in the open air. According to O. Levytsky, it should remind believers the portico of the St. Peter's Basilica in Rome, from which the Pope gives traditional address "The Urbi et Orbi"13.

Thus, in the middle of the $18^{\text {th }}$ century the Cathedral of Dormition received a new architectural image based on of late-baroque style. The logic of these changes generally correlates to the general principles of the late Baroque. However, it cannot but mentioned the role of denomination preferences in the Greek Catholic Church. That was the decision of the Union of Zamość in 1720, in which it was not the last position to maintain properly the existing and build new temples. Therefore, significant rise of the new construction of the Greek Catholic denomination was observed in the second and third quarter of the $18^{\text {th }}$ century. New initiatives were often accompanied by the destruction or radical rebuilding of the old temples (Chełm, Lviv, Pochaiv, etc.). In fact, late baroque transformations of the Cathedral, which apparently in their "old-fashioned" architecture no longer corresponded to the new image needs, should be considered in the context of occidentalization ("westernization").

Unfortunately, further repairs were devastating. Symeon Młocki, the last Greek-Catholic bishop, in 1782 planned to cut stairs in the north-western inner supporting element to the preaching pulpit. The consequences were catastrophic. The weakened support fell, pulling a part of the vaults and roof. The cathedral was open to devastating atmospheric influences, and repair work were conducted slowly. It was placed at the disposal of the Russian state treasury department, and in 1806 he was transferred to the Orthodox department in such a dilapidated state, after Third Partition of Poland. 


\section{Under patronate of Russian ortodox church}

The first half of the $19^{\text {th }}$ century was associated with unsuccessful attempts to rebuild the cathedral. However, the destruction of the temple continued and in 1878 in the official report it was noted that now there are "only the walls"14 (Fig. 4).
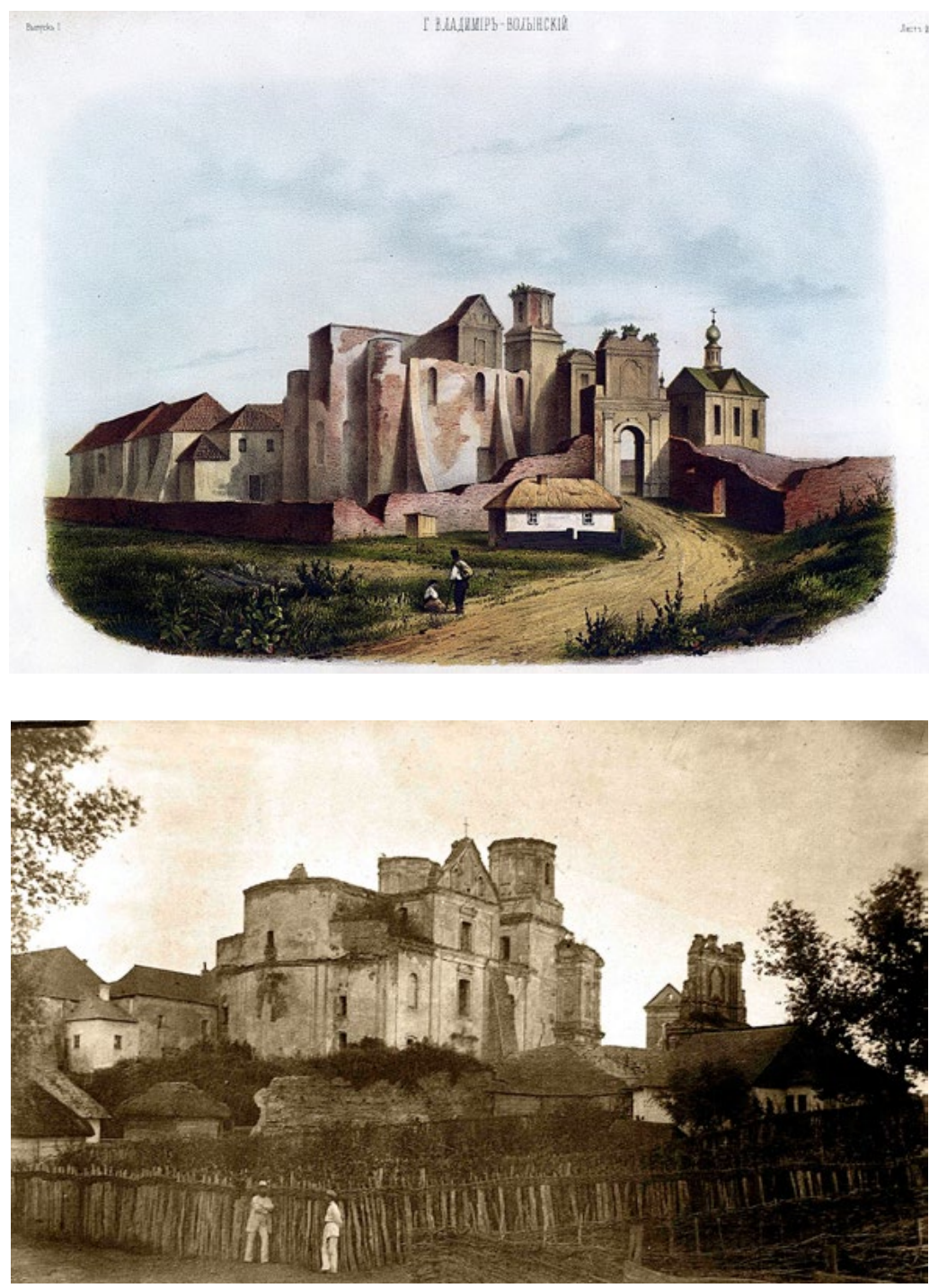

Fig. 4. Ruins of the Cathedral of Dormition. Litograph 1860s. After: Памятникирусскойстарины в западныхгуберниях. Вып.1. СПб. 1868.

Fig. 5. Ruins of the Cathedral of Dormition. Photo by A. Prakhov. 1886. After: Памятники Волыни. Альбом фотографий к археологической поездке проф. А.В. Прахова на Волынь. Collection of National Bibliotheca of Ukraine in Kyiv.

Finally, in 1886, extensive studies of the temple ruins began. In the conditions of active support of the royal power and the Orthodox Synod, the rebuilding of the Assumption Cathedral as one of the most ancient shrines of the Old Ruś era became real. At the same time, the main issue that troubled the researchers and the public was how exactly the architectural forms should be reproduced at the same time. However, the answer to this question was to study the actual state of a semi-destroyed temple.

The well-known Kyiv art expert Professor Adrian Prakhov was to be the first to examine thoroughly the structures and make architectural measurements of the temple ruin. Finally, in 1886, he performed a series of documentary photos that recorded the actual state of the building, in particular its appearance from the north-east (Fig. 5). 


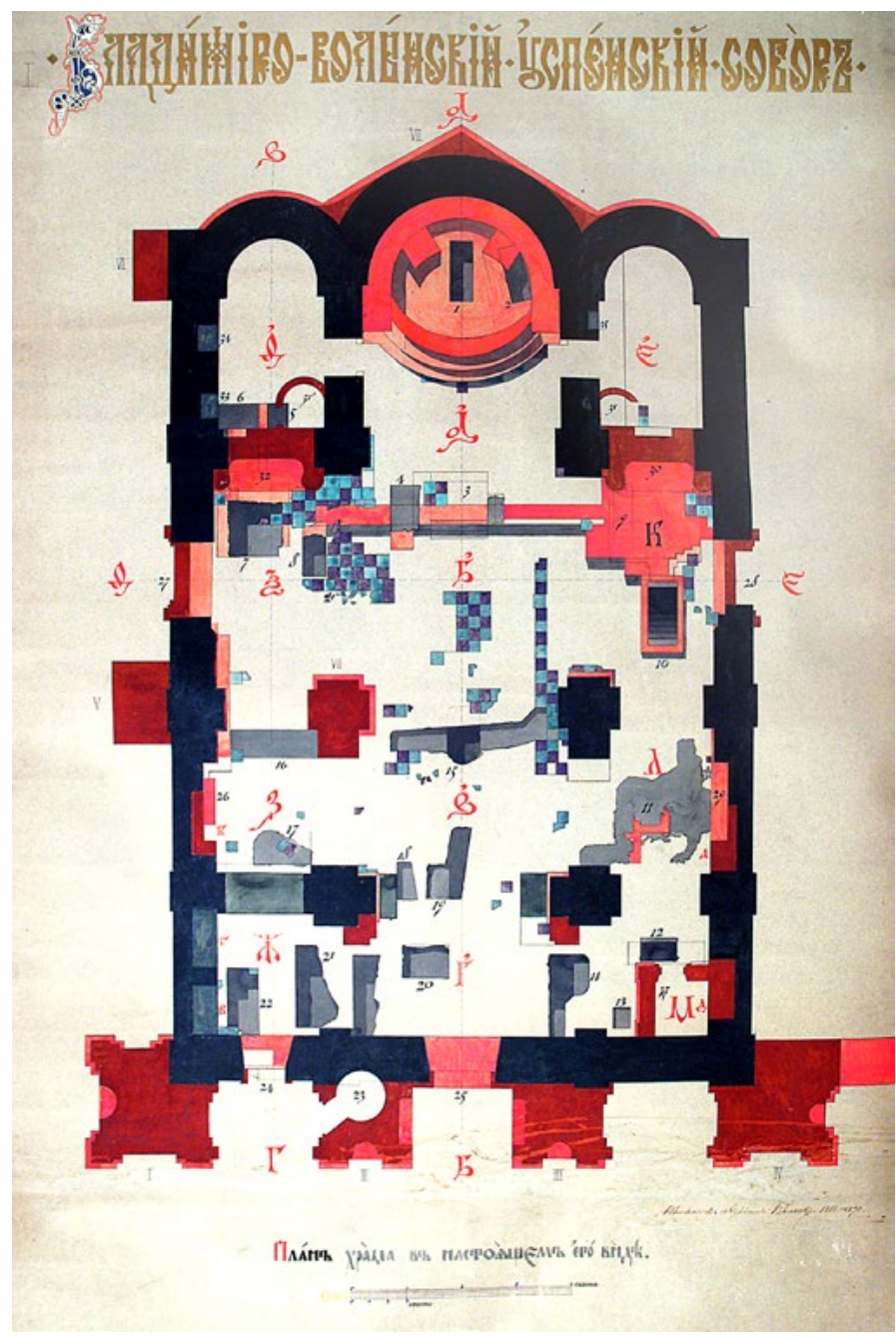

Fig. 6. Plan of the Cathedral of Dormition with structural additions (in red) made in $18^{\text {th }}$ cent. The analytical drawing by A. Prakhov. 1886. Source: A. Prakhov Collection of the Volynian Museum of Regional Studies (VMRS).

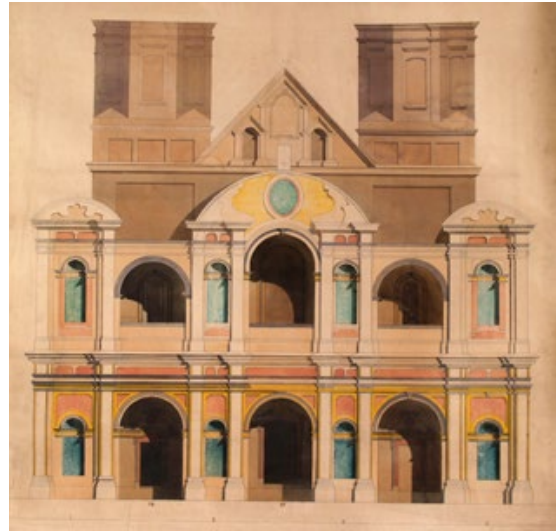

Fig. 7. Western elevation of the Cathedral of Dormition. Drawing by A. Prakhov. 1886. Source: VMRS.

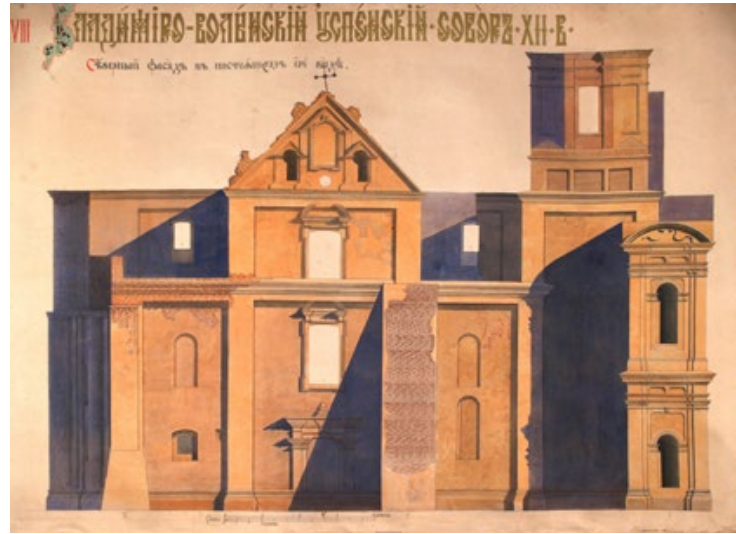

Fig. 8. Nothern elevation of the Cathedral of Dormition. Drawing by A. Prakhov. 1886. Source: VMRS.

A. Prakhov also made a series of detailed dimensional drawings as of 1886. Initially, he recorded a plan of the temple, on which he painted in red all the structural elements not attributed to the original building of the $12^{\text {th }}$ century (Fig. 6). At the same time, he performed detailed measurements of the exterior facades and 
drawings of internal sections. These drawings not only gave a detailed idea on the actual state of the Cathedral at that time but could serve as the source material for the reconstruction project (Figures 7-10). At the same time, they characterize A. Prakhov as a virtuosic master of architectural graphics. His drawings consist of eight large-scale sheets with the reproduction of plans, facades and sections of the Cathedral are now kept in the funds of the Volynian Museum of Regional Studies.

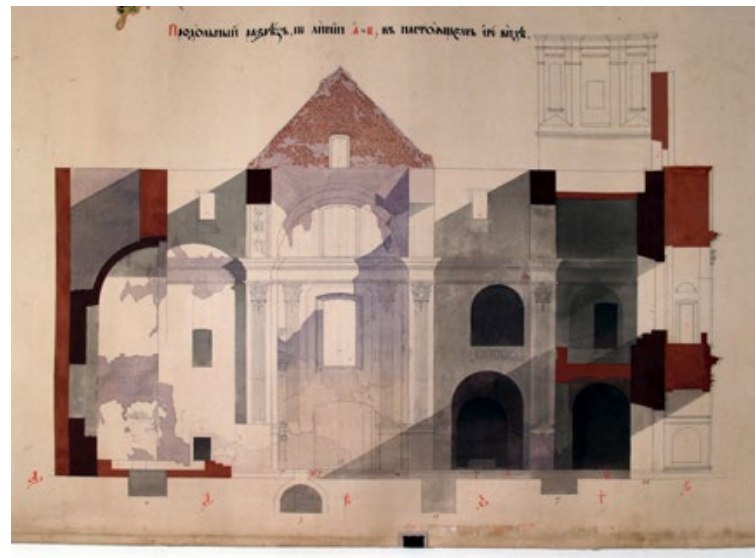

Fig. 9. Longitude section of the Cathedral of Dormition. Drawing by A. Prakhov. 1886. Source: VMRS.

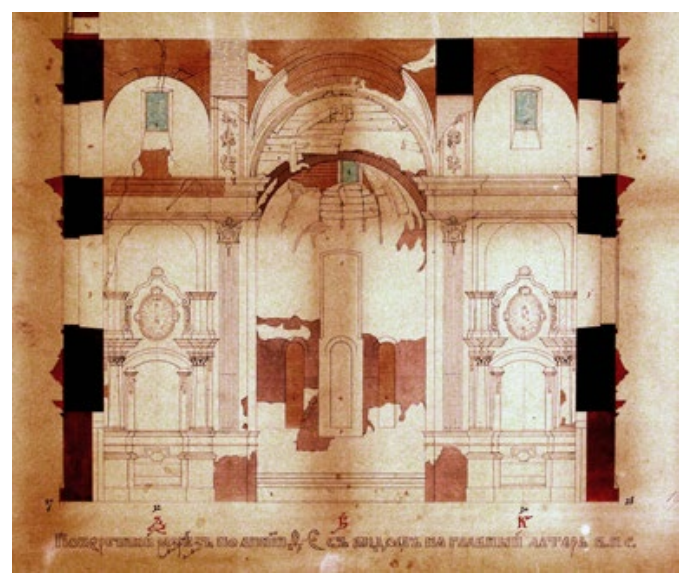

Fig. 10. Cross-section of the Cathedral of Dormition. Drawing by A. Prakhov. 1886 . Source: VMRS.

\section{The reconstruction project by Adrian Prakhov}

After performing a large amount of research works, Professor A. Prahov's attempt to offer his own version of the rebuilding of the Cathedral seems to be quite logical.

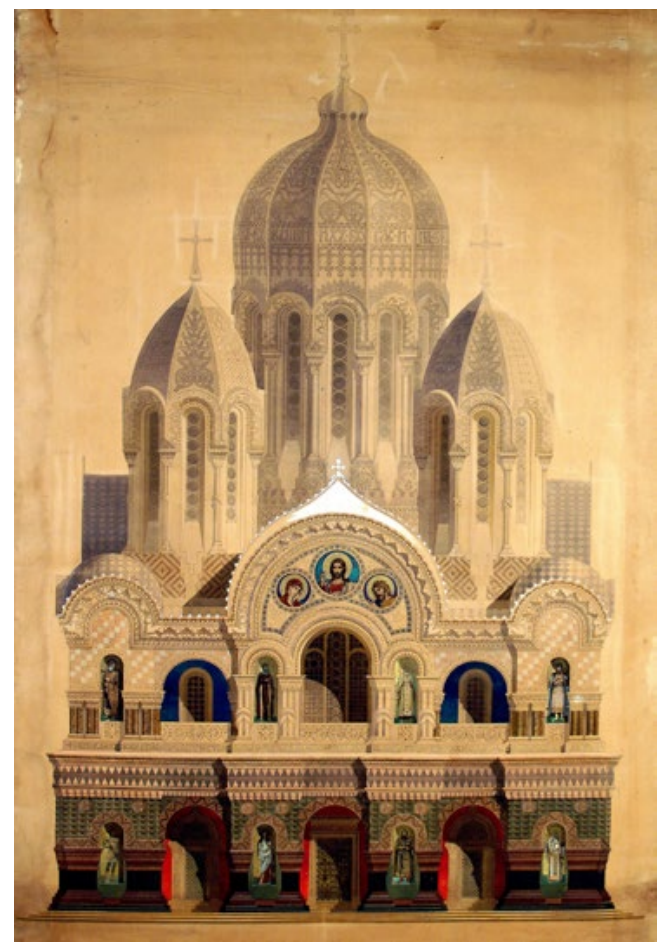

Fig. 11. Project of the Cathedral of Dormition reconstruction. Western elevation. Architect A. Prakhov. 1886. Source: VMRS. 
His design proposal was based on the use of ancient "Greek-Russian forms of the twelfth century"15. The restored temple was supposed to have five-domes. At the same time, the central dome was seen by the author in the form of mitra, and smaller domes - in the form of a skufia. He considered appropriate to preserve partially those architectural forms that appeared in the $18^{\text {th }}$ century, the monumental exonarthex on the western facade. The sculptural and picturesque images of the saints, symbolically associated with the sacred history of Russia (fig. 11), should appear in the niches and on the main pediment. However, such an original project idea did not find support among the public and clergy.

It was decided to continue studying the remains of the temple and make a more acceptable version of the reconstruction based on it, more relevant stylistically to the traditional forms of Russian temples constructed in the Pre-Mongolian age. It was styled as a work of the Old-Russian Chernigiv Architecture School.

\section{The reconstruction project by Grigorii Kotov}

After lengthy professional discussions, the development of a new project was entrusted to St. Petersburg architect Georgii Kotov (1859-1942). His project envisaged the complete destruction of all architectural changes and additions related to the Greek Catholic period. In contrast to the previously proposed A. Prakhov's "five-headed" variant with one helmet-shaped dome on a cylindrical tholobate(drum) was chosen with twelve window openings (Fig. 12).

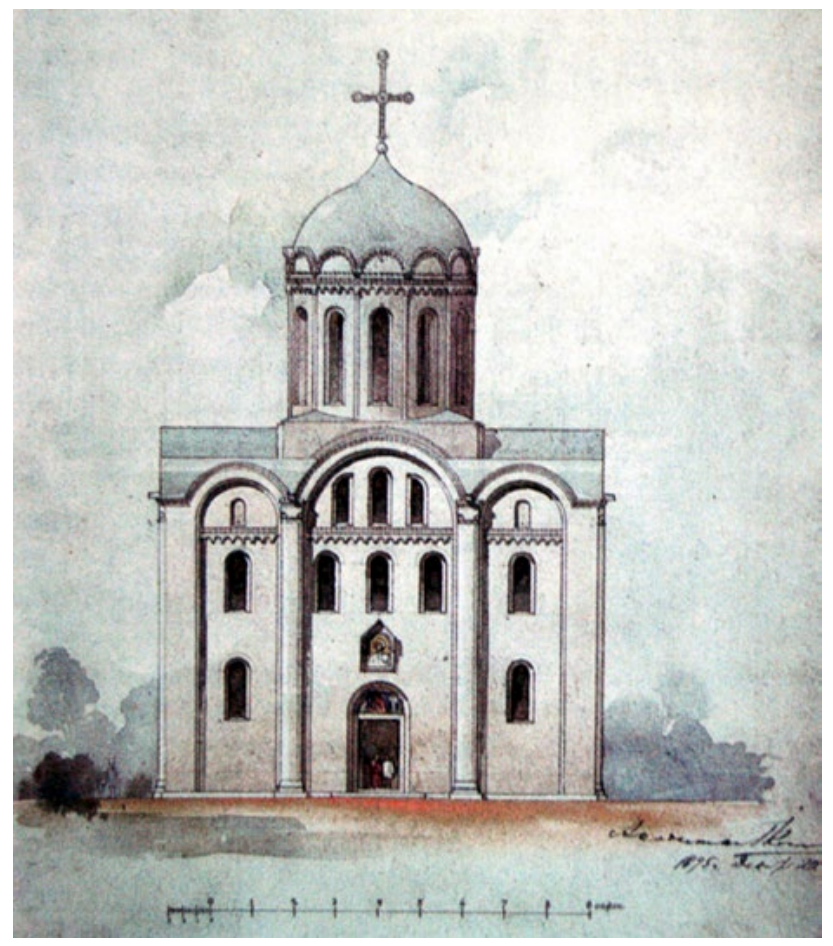

Fig. 12. Project of the Cathedral of Dormition reconstruction. Western elevation. Architect G. Kotov. 1895. Source: Scientific and research museum of the Russian Academy of Arts (St. Petersburg).

Project by G. Kotov was considered by The Imperial Archaeological Commission, with the participation of representatives of the Russian Academy of Arts, the Ministry of Internal Affairs, the leading Russian architects. It was approved in 1896. Reconstruction started immediately and in 1900 there were already official celebrations dedicated to the restoration of the temple. Since then, and to this day, it exists unchanged, and does not remind its Baroque "predecessor" even remotely (Fig. 13). 


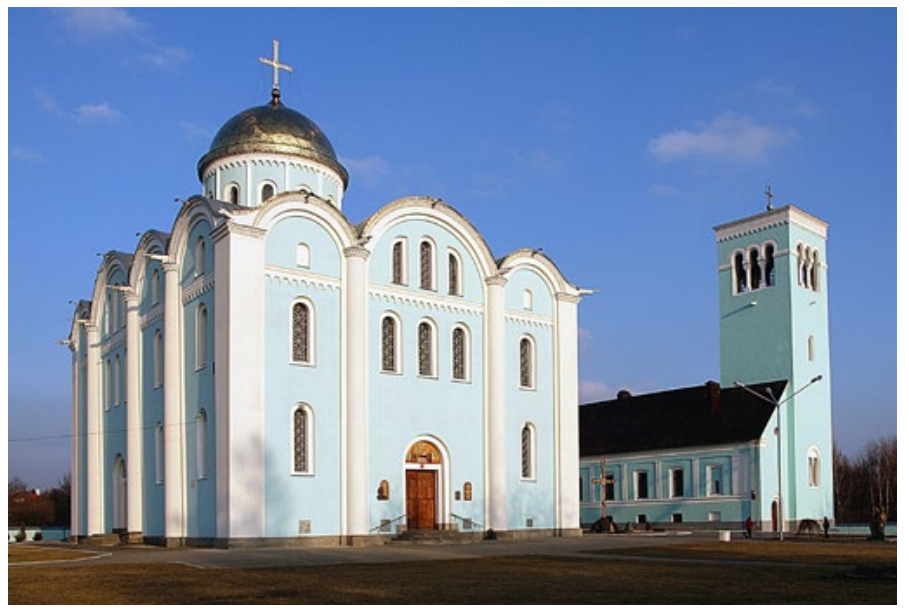

Fig. 13. Volodymyr-Volynskyi. Dormition of the Mother of God Cathedral. The present state. Photo by P. Rychkov. 2011.

The decision of the Russian authorities to eliminate Baroque architectural stylistics of the Cathedral was in the socio-political plane, considering peculiarities of the historical development of this territory. The return to the $12^{\text {th }}$ century model was evident ideological motivation for the Orthodox Church. This should have happened by destroying all the architectural innovations that appeared as if from the desire of the Greek Catholic bishops "to give this Orthodox church a form of Catholic church"16.

In our opinion, Professor A. Prakhov was right in discussion about the ideological bases of reconstruction, proposing to preserve the western façade (exonatherx) and, at the same time, return to the temple the features of Orthodox architecture. In other words, the actual ruin could eventually become the original historical symbiosis of two different architectural and artistic paradigms - eastern and western (respectively, Orthodox and Catholic).

However, the his project was not approved by the Orthodox Synod because of supposedly excessive "Byzantineism". Although the idea of a compromise between time-varying architectural forms within a single building looked rather interesting. However, in the socio-political context of that time, such a decision was unacceptable. Architect G. Kotov in this situation, with all his professionalism, had to unconditionally support the orthodox version of the reconstruction.

\section{Conclusions}

From the historical and cultural point of view, the project had disputable assessement of researchers who emphasized the value of Baroque architecture of the totally deformed the interesting, impressive volume of the Cathedral, which appears today as an inadequate, largely fantastic new concept. "The history of this reconstruction, with the scale of its destruction, compartible to disputable restorations of the ancient churches in Ostrog and Ovruch"17.

At the same time, it was, probably, thebrightest attempt to find its own style for the new Greek-Catholic denomination. This process became widespread in the West Ukrainian and Belarusian lands in the eighteenth century, resulting in several original architectural objects (Chełm, Pochaiv, Buchach, Lviv, Pidubtsi, Polotsk, Mohyliv, etc.). And when the firstPolish-Lithuanian Commonwealth collapsed, the adaptation of liquidated Greek Catholic and Roman Catholic churches to Orthodox stylistic canons became common. Consequently, we can speak of contemporary architectural transmorphism as a rather widespread phenomenon on the Orthodox-Union-Catholic boundary. In this sense, the Cathedral of Dormition in Volodymyr-Volynskyi is an exemplary example. 


\section{References}

[1] Батюшков П. Памятники старины в западных губерниях империи. СПб.: Б.и., 1868. Вып.1. Б.п.

[2] Дверницький Е.Н.Владимиро-Волынский Мстиславский собор 12 в. и предстоящее его обновление // Киевскаястарина. 1886. № 2. С. 837-839.

[3] Каргер М.К. Вновь открытые памятники зодчества ХІІ-ХІІ/вв. во Владимире Волынском // Ученые записки Ленинградского госуниверситета. 1958. №252. Серия исторических аук. Вып.29. С.3-33.

[4] Левицкий О.И. Историческое описание Владимиро-Волынского Успенского храма, построенного в половине XII векакнязем Мстиславом Изяславичем. Киев, 1892. 132с.

[5] Памятники Волыни. Альбом фотографий к археологической поездке проф. А.В. Прахова на Волынь в 1886 г. [Владимир-Волынский], б.г.

[6] Прахов А. В. Об исследовании Мстиславова Владимиро-Волынског собора 12 в.: реферат на Московском археологическом съезде. // Волынские епархиальные ведомости. 1890. № 5. С.162-164.

[7] Pannonopm П.А. Мстиславов храм во Владимире-Волынском // Зограф (Београд).1977, № 7. С. 17-22.

[8] Ричков П. Пізньобарокова трансформація Успенського собору у Володимирі-Волинському // Архітектурна географія бароко в Україні: регіональні особливості та спільні риси: 3бірник наукових праць. Ніжин, 2012. С.79-101.

[9] Betlej A. Pawel Giżycki SJ architekt polski XVIII wieku. Kraków, 2003. 399 s.

[10] Galicki B. Wtodzimierz na Wotyniu. Łuck, 1939. 57 s.

[11] Giżycki J.M. Bazylianie we Włodzimierzu i Trzygórach. Kraków, 1912. VIII, 170 s.

[12] Kowalczyk J. Kierunki w póżnobarokowej architekturze sakralnej na Wotyniu // Sztuka kresów wschodnich. Kraków: 1994. T.1. S. 7-38.

[13] Raczynski J., Walicki M. Z wycieczki naukowej Zakładu architektury polskiej na Wołyń (Włodzimierz Wołyński i Zimno) // Przegląd Historji Sztuki. 1929. Z. 1-2. S. 24-28.

[14] Walicki M. Średniowieczne cerkwie Wtodzimierza // RocznikWołyński. 1931. T.2.S. 371-383.

[15] Źródła dziejowe. T.VI: Rewizya zamków ziemi Wołyńskiej w połowie XVI wieku (1545). Warszawa, 1877. C1X, 153, VIII s. 